\title{
Expression of the insulin-like growth factor II gene in polychlorinated biphenyl exposed female mink (Mustela vison) and their fetuses
}

\author{
B-M Bäcklin, Å Gessbo, M Forsberg, A Shokrai, B Rozell, W Engström
}

\begin{abstract}
Aim-To study how polychlorinated biphenyls (PCBs) affect fetal growth and the expression of the insulin-like growth factor (IGF II) gene in the mink (Mustela vison).

Methods-Ten female mink were each exposed to 0.65 or $1.3 \mathrm{mg}$ Clophen A50/ day, respectively, during the reproductive season. The numbers and sizes of viable fetuses were recorded. The expression of the IGF II gene was studied by northern blotting using a mink specific IGF II cDNA probe.

Results-The number of viable fetuses decreased after PCB exposure in a dose dependent fashion. Expression of the IGF II gene in adult livers from PCB exposed animals was decreased, compared with control animals, in a dose dependent fashion. In contrast, IGF II expression in placentas and fetuses was unaltered. Furthermore, the maternal excretion of urinary cortisol increased in both exposed groups during the implantation period. Conclusions-Expression of the IGF II gene is downregulated by PCB exposure in the adult liver. There is also an indication that the regulation of the expression of this gene differs between adult and fetal life.

(F Clin Pathol:Mol Pathol 1998;51:43-47)
\end{abstract}

Keywords: insulin-like growth factor II; polychlorinated biphenyls; mink

Department of Pathology, Faculty of Veterinary Medicine, Swedish University of Agricultural Sciences, S-750 07 Uppsala, Sweden

B-M Bäcklin

Å Gessbo

A Shokrai

B Rozell

W Engström

Department of Clinical Chemistry, Faculty of Veterinary Medicine, Swedish University of Agricultural Sciences M Forsberg

Correspondence to: Dr Engström.

Accepted for publication 4 December 1997 characteristics with the mink) that suffer risk extinction as a result of massive exposure to chemical waste. ${ }^{1}$
Several studies have shown that exposure to PCBs causes fetal death in mink. ${ }^{2-8}$ However, ovulation and implantation seem to be normal in mink after exposure to PCBs. ${ }^{35-10}$ Furthermore, the excretion of urinary cortisol in pregnant, PCB exposed mink has been found to be significantly raised early in gestation. ${ }^{11}$

Embryonic viability is dependent on adequate nutrition, growth factors, and external endocrine stimuli. The insulin-like growth factors, IGF I and IGF II, are members of a family of structurally related peptides that are important for animal development. ${ }^{12}$ Both the IGF I and II genes are evolutionary well conserved, at least in their coding sequences, and transcripts show extensive homology between species. ${ }^{13}$ Whereas IGF I expression can be stimulated by pituitary growth hormone, IGF-II production cannot. ${ }^{14}$ In this study, expression of the IGF II gene was altered in PCB exposed adult mink. This is in contrast to the fetus and placenta, where IGF II expression was similar in the PCB exposed and control animals.

\section{Material and methods}

ANIMALS AND EXPERIMENTAL DESIGN

The mink is a seasonal breeder, with a breeding season that starts in late February and lasts until the end of March in the northern hemisphere. Ovulation is induced by the copulatory act. The implantation of ova is delayed and the embryo can remain in the blastocyst stage for up to 49 days postcoitus. The gestational time, including the period of delay varies from 42 to 79 days, with a mean length of 51 days. Parturition takes place in the last week of April and continues until the middle of May, with a peak from about the 3-8 May. The crown-rump length is approximately $75 \mathrm{~mm}$ and the weight is $10 \mathrm{~g}$ at birth. A prenatal mortality in early gestation of $5.8 \%$ between the 11 and 25 April and of $35.8 \%$ between the 25 April and birth is normal.

Thirty proven breeders of two year old standard, dark, female mink were housed at a private farm near Uppsala, Sweden. The animals were individually caged. Thirty mink were allocated into three groups: the control group, animals receiving $0.65 \mathrm{mg}$ Clophen A50/day, and animals receiving $1.3 \mathrm{mg}$ of Clophen A50/day.

The exposure started on 2 March and the mink were mated between 12 and 27 March with non-exposed males. This gives an exposure time ranging from 79 to 94 days. The feed was supplemented with PCB dissolved in peanut oil in the exposed groups, and with peanut 


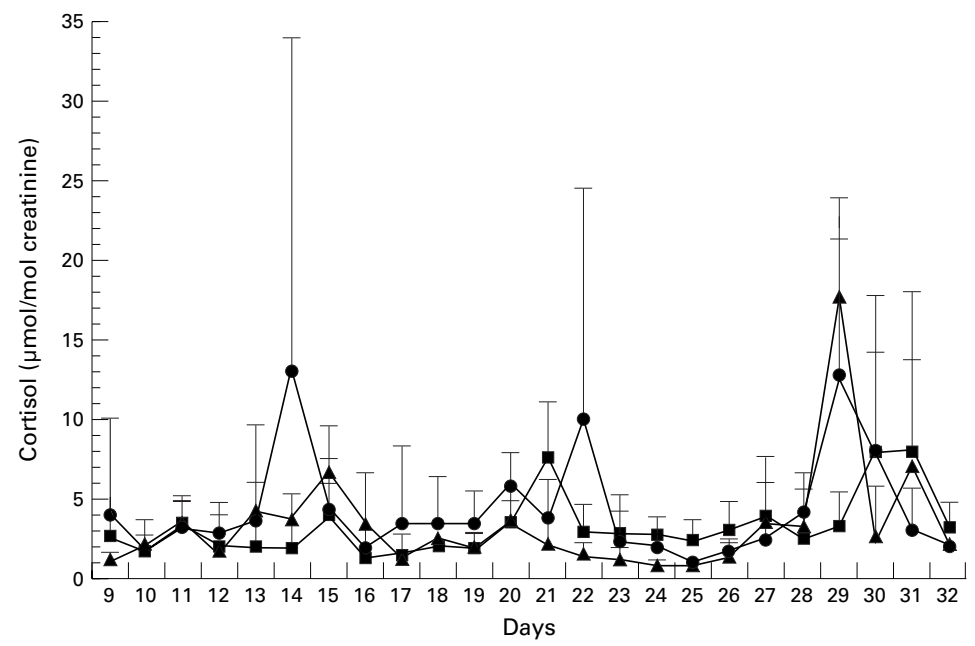

Figure 1 The temporal relation (days postcoitus) between cortisol excretion and polychlorinated biphenyl (PCB) administration. Total urine was collected daily from five randomly selected animals from the control group (squares) and groups exposed to either 0.65 (circles) or $1.3 \mathrm{mg}$ (triangles) $\mathrm{PCB} / \mathrm{kg} /$ day. The ratio of cortisol to creatinine was calculated, the data from the five animals in each group were pooled, and the mean values and standard deviations were calculated.

oil only in the control group. The feed consisted of: Baltic whole cod, $30 \%$; whole herring, $10 \%$; herring offal, $10 \%$; slaughter offal, $15 \%$; whole hens, $8 \%$; mink flour (barley, oats, and wheat, which are mixed, boiled, and dried), $12 \%$; rapeseed oil, $2 \%$; and vitamins. Water was provided ad libitum.

The animals were killed by electrical stunning and cervical dislocation in midgestation, on 21 or 24 April (28-43 days postcoitus). One animal that received $0.65 \mathrm{mg}$ PCB and four animals that received $1.3 \mathrm{mg}$ PCB were excluded from the evaluation because they showed no signs of implantation.

Immediately after cervical dislocation the animals were dissected and the proportion of apparently viable fetuses was recorded. The body and liver of the adults were weighed and the numbers of placentas and fetuses, and the fetal weights and lengths (crown-rump) were recorded. Samples from adult livers, placentas, and fetuses were frozen in liquid nitrogen and stored at $-80^{\circ} \mathrm{C}$ until further analysis. Tissue samples were analysed from three animals in each exposed group and from three control animals.

Table 1 Summary of the reproductive results based on PCB exposure

\begin{tabular}{llll}
\hline & Control & 0.65 mg/day & 1.3 mg/day \\
\hline Number of animals & 10 & 10 & 10 \\
Coitus to death (days) & $28-37$ & $28-44$ & $30-43$ \\
Mean body weight at death (g) & 1057 & 1206 & 1125 \\
Mean liver weight (g) & 38.9 & 51.6 & 50 \\
Animals with implantations & 10 & 9 & 6 \\
Animals containing only dead fetuses or & & & 2 \\
$\quad$ degenerate placentas & 0 & 1 & $66(9-14)$ \\
Placentation sites (range) & $83(4-13)$ & $74(5-15)$ & $23^{\star}$ \\
Placentas with viable fetuses & $8-50$ & $54^{\star}$ & $7-15^{\star} \dagger$ \\
Range of fetal crown-rump lengths (mm) & $7-50-53$ & $24-260^{\star} \ddagger$ \\
Range of fetal mean weights (mg) & $289-3625 \ddagger$ & $154-6015$ & \\
\hline
\end{tabular}

${ }^{\star} \mathrm{p}<0.025$.

†Mean length $11 \mathrm{~mm}$.

¥One animal in the group had nine placentation sites of which eight were degenerate. The only viable fetus was $24 \mathrm{~mm}$ crown-rump length and weighed $919 \mathrm{mg}$.
PREPARATION OF THE PCB DOSE

Clophen A50 (1.4 g; Bayer AG, Stockholm, Sweden) was dissolved in $5 \mathrm{ml}$ of diethylether and mixed with $484 \mathrm{~g}(538.5 \mathrm{ml})$ peanut oil (Apoteksbolaget AB, Uppsala, Sweden) using a magnetic stirrer. The ether was removed in a stream of nitrogen. The final concentration was $2.6 \mathrm{mg}$ of Clophen A50/ml peanut oil.

GLUCOCORTICOID MEASUREMENTS

Five mink from each group were selected randomly for glucocorticoid excretion analysis (fig 1). Urine aliquots (24 hour) were collected daily. All urine was collected and filtered through a membrane to remove contaminating debris. To each urine collection container, $1 \mathrm{~g}$ of boric acid was added as preservative. Samples were stored at $-20^{\circ} \mathrm{C}$ until assay. The determination of urinary cortisol was performed as described previously. ${ }^{11}$ The intraassay coefficient of variation was below $10 \%$ for concentrations in the interval $18-1294 \mathrm{nmol} / 1$. The inter-assay coefficients of variation for two control samples were $16 \%(29.9 \mathrm{nmol} / \mathrm{l})$ and $7 \%(109.4 \mathrm{nmol} / \mathrm{l})$. Creatinine was measured by the Jaffe reaction at $500 \mathrm{~nm}$ (Cobas Mira; Hoffman LaRoche and Co, Basel, Switzerland) according to the manufacturer's instructions. The inter-assay coefficient of variation was $1.8 \%(192 \mathrm{mmol} / \mathrm{l})$.

\section{RNA ISOLATION}

Total RNA from fetal, placental, and adult liver tissue was isolated using the guanidinium thiocyanate acid phenol/chloroform protocol as described previously. ${ }^{15}$ Poly A+ RNA was isolated from $1 \mathrm{mg}$ of total RNA using a standard oligo dT cellulose purification method. ${ }^{16}$

NORTHERN BLOT ANALYSIS

Aliquots of $2 \mu \mathrm{g}$ of poly A+ RNA or $20 \mu \mathrm{g}$ of total RNA from adult livers, fetal livers, or placentas were loaded on to each lane of a $1 \%$ agarose, $2.2 \mathrm{M}$ denaturing formaldehyde gel. The quantity of RNA loaded on to each column was checked by spectrophotometry followed by titration on an ethidium bromide stained minigel. Human bulk RNA containing $18 \mathrm{~S}$ and $28 \mathrm{~S}$ RNA provided size markers. The RNA was transferred to a biodyne A nylon membrane (Pall, London, UK) by capillary force. The probe was a 387 base pair mink cDNA fragment which covers the coding sequence for IGF II. ${ }^{17}$ The probe was labelled with ${ }^{32} \mathrm{P}$-dCTP using a multiprime labelling kit (Amersham, Amersham, UK). The filter was prehybridised, hybridised overnight in 50\% formamide at $42^{\circ} \mathrm{C}$, and washed at a final stringency of $1 \times$ SSC $(0.15 \mathrm{M}$ sodium chloride, $0.015 \mathrm{M}$ sodium citrate) at $55^{\circ} \mathrm{C}$. The filter was exposed for $24-96$ hours at $-70^{\circ} \mathrm{C}$. To achieve exact quantitation of IGF II expression, filters were stripped of bound probe and rehybridised with a murine 3-hydroxy 3-methyl glutaryl (HMG) CoA-reductase (pRED 10) cDNA control probe. ${ }^{18}$ The relative intensities were determined using a Shimatzu laser scanning densitometer. The IGF II and HMG CoA reductase values were then divided to 


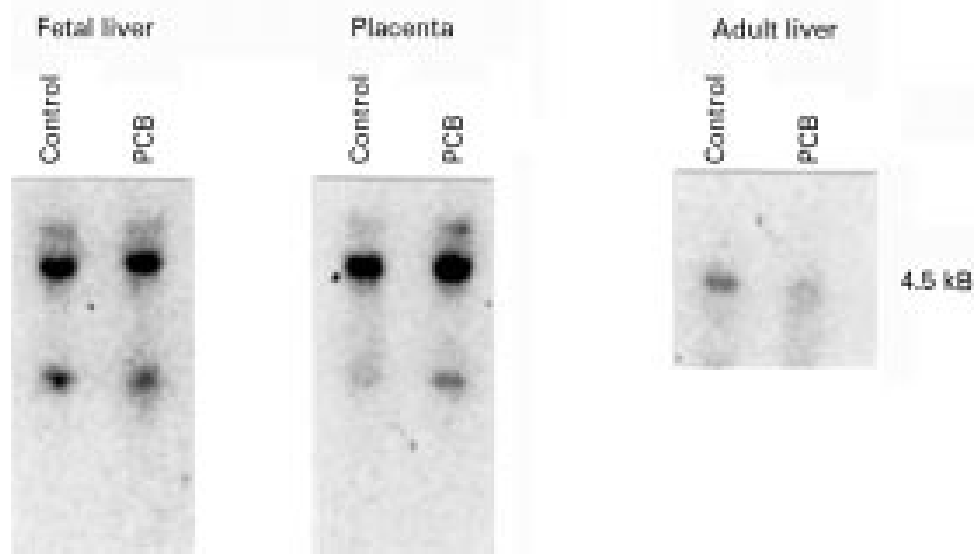

Figure 2 Expression of the insulin-like growth factor (IFG) II gene in fetal liver, placenta, or adult liver obtained from control animals or animals exposed to $1.3 \mathrm{mg} P C B / \mathrm{kg}$ body weight/day. Hepatic $m R N A$ was prepared and run on a denaturing gel that was subsequently subjected to a northern transfer to a Biodyne membrane. The filter was hybridised with a mink IGF II cDNA probe. ${ }^{18}$ After exposure, the filter was stripped of bound probe and rehybridised with a heterologous "housekeeping" probe (murine 3-hydroxy 3-methyl glutaryl (HMG) CoA reductase; pRED10) to ensure comparable loading in both lanes. The figure shows two representative samples chosen from panels from at least two different animals. ranges of placentation sites, fetal death, body weights, and liver weights of the adults as well as body weights and lengths (crown-rump) of fetuses are summarised in table 1 for the three groups. It was found that the number of placentas that contained viable fetuses, as judged by macroscopical examination, decreased with increasing concentration of PCB. Moreover, when the high dose of PCB was given, the crown-rump length and the fetal weight were significantly $(p<0.025)$ decreased in comparison with healthy animals.

The amount of PCB consumed with the Baltic cod and herring was estimated to be $8 \mathrm{mg} /$ day (a total of $0.42 \mathrm{mg}$ ) for both groups.

EFFECTS OF PCB ON GLUCOCORTICOID

EXCRETION

Urine samples were collected from five mink in each of the three experimental groups. The urinary excretion of cortisol, adjusted for differences in urinary volume by simultaneous determination of urinary creatinine, is given in fig 1 .

It was found that on and around day 29 postcoitus, glucocorticoid excretion increased significantly in the PCB exposed animals. The increase was transient and the excretion decreased promptly.

The Student's $t$ test was used to evaluate the significance of differences between sample means.

\section{Results}

EFFECTS OF PCB ON FETAL GROWTH AND VIABILITY

All 10 animals in the control group showed placentation sites. In the lower dose group (0.65 mg Clophen/day), nine of 10 animals showed placentation sites, and in the higher dose group (1.3 mg Clophen/day), six of 10 animals showed placentation sites. There was no difference in the numbers of placentation sites between the control group and the exposed groups in implanted animals. The

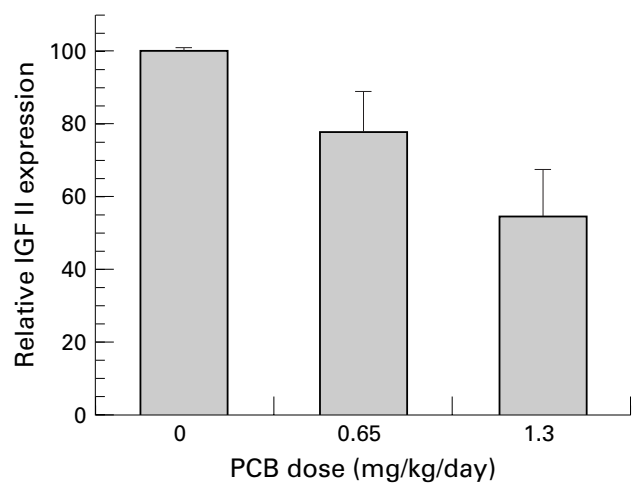

Figure 3 Relation between polychlorinated biphenyl (PCB) exposure and insulin-like growth factor (IGF) II $m R N A$ expression in adult liver. After hybridisation with an IGF II cDNA probe, filters were stripped of bound probe and rehybridised with a heterologous "housekeeping" probe (murine 3-hydroxy 3-methyl glutaryl (HMG) CoA reductase; $p R E D 19)$. The relative intensities of the bands were determined by scanning densitometry and the relation calculated by dividing the integrated areas. Each bar is based on four scannings of blots from two different animals. Both of the two PCB concentrations resulted in significant reduction $(p<0.025)$ in relative IGF II expression.

\section{EFFECTS OF PCB ON EXPRESSION OF THE IGF II} GENE IN THE FETUS AND PLACENTA mined by northern blotting, gave rise to multiple transcripts. The transcripts in fetuses and placentas were quantitated and found to be comparable in control and PCB exposed animals (fig 2).

EFFECTS OF PCB ON IGF II GENE EXPRESSION IN THE ADULT LIVER

IGF II gene expression in the adult liver gave rise to a single, 4.6 kilobase transcript (fig 2), the concentration of which was dependent upon the PCB dose. By scanning the intensities of the northern blot bands of IGF II and the HMG CoA reductase, and calculating the relative expression of IGF II, it was possible to show a PCB dose dependent, significant decrease $(p<0.025)$ in expression of the IGF II gene (fig 3).

\section{Discussion}

The cause of fetal death in relation to PCB exposure is not yet fully understood. In this study we confirm earlier reports of fetal death, without reduction in the numbers of implantation sites, in implanted PCB treated mink..$^{2-8}$ Also, in the present study, enhanced secretion of urinary cortisol were seen on and around day 29 postcoitus in both PCB exposed groups. This is in accord with a previous study, in which pregnant mink of similar age were exposed to a higher dose ( $2 \mathrm{mg} /$ day) of Clophen A50. These animals also showed higher excretion of cortisol during early gestation $^{11}$ and higher numbers of fetal deaths, ${ }^{8}$ as compared with both controls and the PCB exposed animals in the present study. These
IGF II gene expression in the fetuses, as deter- 
results indicate a causative relation between the dose of Clophen A50 and the excretion of cortisol as well as the numbers of dead fetuses.

In the present study, the sizes of the IGF II transcripts in mink were in accord with those reported in a previous study. ${ }^{17}$ The expression of the IGF II gene in adult liver was repressed by PCB exposure, while the expression in fetuses and placentas appeared to be unaltered. Transcription from the fetal IGF II promoters shortly after birth has been shown to be glucocorticoid sensitive in rodents. ${ }^{19}$ Furthermore, injections of glucocorticoids decreased IGF II expression in the fetal rat liver. ${ }^{20}$ These findings can be explained by the fact that several putative glucocorticoid responsive elements have been identified upstream of the rodent P3 IGF II promoter. ${ }^{19}$ However, there is not sufficient knowledge of either the mink IGF II gene structure or its regulatory elements to allow firm conclusions. Hence, parallels between the observed downregulation of IGF II gene expression after PCB exposure and raised glucocorticoid excretion must remain speculative. The possibility that there are specific intermediaries between the binding of key steroids to their receptors and activation of the IGF II gene must also be taken into account.

It is more difficult to purify RNA from liver tissue than from other organs and to ensure that altered gene expression in the adult liver did not reflect impaired organ function, both IGF II and HMG CoA reductase gene expression were determined. It has been recorded in several species that PCB exposure causes hepatic fatty changes and degeneration. Moreover, adult mink exposed to $2 \mathrm{mg}$ Clophen A50/day during gestation display centrilobular fatty change in the liver. ${ }^{21}$ In the same experiment, raised concentrations of alanine aminotransferase were also reported. ${ }^{22}$ However, because expression of the HMG CoA reductase gene in the PCB exposed mink was similar to that in control animals, it is suggested that the observed downregulation of the IGF II gene does not result from hepatic lesions or RNA degradation

The mechanism by which IGF II gene expression is affected in the adult is probably different from that in the fetus. In all mammals examined so far, differences in the transcriptional pattern indicate separate regulatory pathways in adult and fetal life. The mechanisms utilised include alternative promoter usage as well as different splicing mechanisms for the IGF II gene. ${ }^{23}$ Unlike the IGF I gene, which in adults is regulated by pituitary growth hormone, ${ }^{14}$ the main regulation of IGF II remains to be elucidated.

It has been shown that in the fetus and placenta, the expression of IGF I and IGF II is influenced by insulin and nutritional factors. PCBs have been reported to reduce food consumption $^{24}$ and inhibit absorption of glucose. ${ }^{25} 26$ In the present experiment, no differences were found between control and exposed animals, with regard to IGF II expression in fetuses or placentas. However, IGF II expression was measured in the fetal liver rather than whole embryos.
In conclusion, this study has shown that transcription of the IGF II gene in the adult liver was repressed after exposure to Clophen A50 in a dose dependent way. In contrast, this PCB did not alter expression in fetal livers and placentas. To complete these observations, further studies are needed to characterise the regulatory elements of the mink IGF II gene and to examine how the IGF II protein is affected by variations in the expression of IGF receptors and binding proteins.

This investigation was supported by grants from Magnus Bergvalls stiftelse. The authors also would like to thank Dr Göran Jonsäll at the National Laboratory of Agricultural Chemistry (SLL) for the gift of Clophen A50, Dr Paul N Schofield for valuable suggestions throughout the course of this experience of mink and also for his excellent care and handling of the animals.

1 Bäcklin BM. Studies on reproduction in female mink (Mustela vison) exposed to polychlorinated biphenyls. $\mathrm{PhD}$ Thesis, Swedish University of Agricultural Sciences, 1996.

2 Aulerich RJ, Ringer RK, Iwamoto S. Reproductive failure and mortality in mink fed Great Lakes fish. $\mathcal{F}$ Reprod Fertil 1973;19(suppl):365-76.

3 Aulerich RJ, Bursian SJ, Breslin WJ, et al. Toxicological manifestations of $2,4,5,2^{\prime}, 4^{\prime}, 5^{\prime}-2,3,6,2^{\prime}, 3^{\prime}, 6^{\prime}-$ and $3,4,5$, $3^{\prime}, 4 ', 5$ ' hexachlorobiphenyl and Aroclor 1254 in mink. $\mathcal{F}$ Toxicol Environ Health 1985;15:63-79.

4 Aulerich RJ, Ringer RK. Current status of PCB toxicity to mink, and effect on their reproduction. Arch Environ Contam Toxicol 1977;5:279-92.

5 Jensen S, Kihlström JE, Olsson M, et al. Effects of PCB and DDT on mink (Mustela vison) during reproductive season. Ambio 1977;6:239-45.

6 Bleavins MR, Aulerich RJ, Ringer RK. Polychlorinated biphenyls (Aroclors 1016 and 1242): effects on survival and reproduction in minks and ferrets. Arch Environ Contam Toxicol 1980;9:627-35.

7 Gilette DM, Corey RD, Lowenstine LJ, et al. Comparative toxicology of tetrachlorobiphenyls in mink and rats. II. toxicology of tetrachlorobiphenyls in mink
Pathology. Fundam Appl Toxicol 1987;8:5-14.

8 Kihlström JE, Olsson M, Jensen S, et al. Effects of PCB and different fractions of PCB on the reproduction of the mink (Mustela vison). Ambio 1992;21:563-9.

9 Bäcklin BM, Bergman A. Morphological aspects on reproductive organs in female mink (Mustela vison) exposed to polychlorinated biphenyls and fractions thereof. Ambio 1992;21:596-601.

10 Platonow NS, Karstad LH. Dietary effects of polychlorinated biphenyls on mink. Can f Comp Med 1973;37:391400.

11 Patnode KA, Curtis LR. 2,2',4,4'.5,5'- and 3,3 .4.4 .5.5 hexachlorobiphenyl alteration of uterine progesterone and estrogen receptors coincides with embryotoxicity in mink

(Mustela vison). Toxicol Appl Pharamacol 1994;127:9-18.

Madej A, Forsberg M, Edqvist L-E. Urinary excretion of
cortisol and oestrone sulfate in pregnant mink fed PCB and cortisol and oestrone sulfate in pregnant
fractions of PCB. Ambio 1992;21:582-5.

13 Han VKM, Hill DJ. The involvement of insulin-like growth factors in embryonic and fetal development. In: Schofield, $\mathrm{P}$, ed. The insulin 1ike growth factors, structure and biological functions. Oxford: Oxford University Press, 1992:178-220.

14 Ward A, Ellis C. The insulin like growth factor genes. In: Schofield, P, ed. The insulin like growth factors, structure and biological functions. Oxford: Oxford University Press, 1992: 45-79.

15 Daughaday WH. The historical evolution of concepts of the role of the insulin-like growth factors. In: Schofield, P, ed. The insulin like growth factors, structure and biological functions. Oxford: Oxford University Press, 1992:5-11.

16 Chomczynski RM, Sscchi N. Single step method of RNA-isolation by guanidinium thiocyanate-phenolchloroform extraction. Anal Biochem 1987;162:156-9.

17 Hyldahl L, Engström W, Schofield P. Stimulatory effects of insulin like growth factors on DNA synthesis in the human insulin like growth factors on DNA synthesis in the human

embryonic cornea. F Embryol Exp Morphol 1986;98:71-83.
18 Ekström TJ, Bäcklin B-M, Lindqvist Y, et al. Insulin like growth factor II in the mink (Mustela vison). Determination of a cDNA nucleotide sequence and developmental regulation of its expression. Genet Comp Endocrinol 1993;90:243-50.

19 Engström W, Granerus M, Sachsenmaier W. Differential gene expression of 3-hydroxy 3-methylglutaryl coenzyme A reductase and $\mathrm{N}$-myc during the synchronous nuclear cycle of Physarum polycephalum. Cell Biol Int Rep 1992;16: 1133-7.

20 Beck F, Samani NJ, Senior P, et al. Control of IGF II mRNA levels by glucocorticoids in the neonatal rat. $7 \mathrm{Mol}$ Endocrinol 1988;1:R5-8.

21 Levinowitz A, Norstedt G. Developmental and steroid hormonal regulation of IGF II expression. Mol Endocrinol 1989;3:797-804

22 Bergman A, Bäcklin B-M, Jarplid B, et al. Influence of commercial polychlorinated biphenyls and fractions thereof on 
liver histology in female mink (Mustela vison). Ambio 1992;21:591-5.

23 Edqvist L-E, Madej A, Forsberg M. Biochemical blood parameters in pregnant mink fed $\mathrm{PCB}$ and fractions of

24 Schofield P, Tate V. Regulation of human insulin like growth factor II transcription in fetal and adult tissues. Development 1987;100:693-704.
25 Sanders OT, Zepp RL, Kirkpatrick RL. Effect of PCB ingestion on sleeping times, organ weights, food consumption, serum corticosterone and survival of Environ Contam Toxicol 1974;12:394-9.

26 Nishihara Y, Utsumi K. Effects of polychlorinated biphenyls (Kanechlor 400) on the potassium and glucose permeability of human erythrocyte membranes. Bull Environ Contam Toxicol 1982;29:208-13.

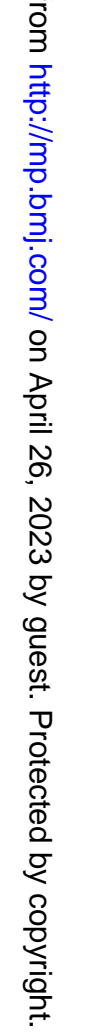

